"Sustaining small businesses in emerging economies: an examination of the pre and post startup ramifications"

\begin{tabular}{|c|c|}
\hline AUTHORS & Chux Gervase Iwu iD https://orcid.org/0000-0002-6290-9864 \\
\hline ARTICLE INFO & $\begin{array}{l}\text { Chux Gervase Iwu (2017). Sustaining small businesses in emerging economies: } \\
\text { an examination of the pre and post startup ramifications. Problems and } \\
\text { Perspectives in Management, 15(1-1), 227-236. doi:10.21511/ppm.15(1- } \\
\text { 1).2017.10 }\end{array}$ \\
\hline DOI & http://dx.doi.org/10.21511/ppm.15(1-1).2017.10 \\
\hline RELEASED ON & Thursday, 11 May 2017 \\
\hline RECEIVED ON & Tuesday, 23 August 2016 \\
\hline \multirow[t]{2}{*}{ ACCEPTED ON } & Thursday, 08 December 2016 \\
\hline & $(\mathrm{cc})$ EY-NC \\
\hline LICENSE & $\begin{array}{l}\text { This work is licensed under a Creative Commons Attribution-NonCommercial } 4.0 \\
\text { International License }\end{array}$ \\
\hline JOURNAL & "Problems and Perspectives in Management" \\
\hline ISSN PRINT & $1727-7051$ \\
\hline ISSN ONLINE & $1810-5467$ \\
\hline PUBLISHER & LLC "Consulting Publishing Company "Business Perspectives" \\
\hline FOUNDER & LLC "Consulting Publishing Company "Business Perspectives" \\
\hline
\end{tabular}

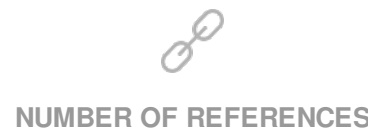

22
NUMBER OF FIGURES

5
NUMBER OF TABLES

4

(C) The author(s) 2022. This publication is an open access article. 


\title{
Sustaining small businesses in emerging economies: an examination of the pre and post startup ramifications
}

\begin{abstract}
Set in the Western Province of South Africa, this study is centred on a group of small business owners who received financial support from a leading South African business developer. The main aims were to obtain from the recipients what they envisaged as their main challenges, and to compare those challenges at a later stage to get a better understanding of the real challenges of small business pre and post startup. The ultimate benefit will be to report on these to inform practitioners and researchers so that every stakeholder can have a fresher insight into this phenomenon with the hope that much more concrete discussions and interventions may emerge. This longitudinal study adopted the mixed method, specifically the use of a questionnaire and a semi-structured interview schedule. This method enabled the researcher to gain a better understanding of the issues at play with respect to first time recipients of funds, as well as engage intimately with them in order to obtain salient information regarding challenges of small business pre and post business startup. Interestingly, most participants indicated that almost all the items in the questionnaire were major challenges. This study should not only generate the necessary discussions among practitioners and scholars on small business growth constraints in South Africa, but, at the same time, uncover through such discussions, some of the undocumented challenges of small businesses in emerging markets so that the chances of survival of small businesses beyond the 2-3 year mark are improved.
\end{abstract}

Keywords: employee management in small businesses, trust issues in small businesses, agency funding, female entrepreneurs, business networks, mentoring, business support agencies, emerging markets.

JEL Classification: I250, M160, M210, O120.

Received on: $23^{\text {rd }}$ of August, 2016.

Accepted on: $8^{\text {th }}$ of December, 2016.

\section{Introduction}

This paper reports the findings of a study that began in early 2012. It centers on a group of small business owners who received funding from a leading South African small business developer (the agency refuses to disclose its identity). The amount ranged from ZAR50 000 to ZAR75 000. The objectives were two-fold: (1) to find out from the recipients what they envisaged as their main challenge(s) with respect to setting up their prospective businesses and maintaining their existing ones, respectively, and (2) to check up on them after about 2-3 years to find out how well or poorly they were doing.

There were 27 recipients comprising 11 females and 16 males. Their initial task with respect to this study was to simply identify from a list of small business challenges (see Table 2 below), the items they envisaged as their major or minor challenges.

It was agreed between the researcher and the recipients that another meeting would be scheduled for about the 2nd quarter of 2014. In the last quarter of 2014, the researcher contacted them to set up a schedule of visits. Of the 27 , only 24 responded. Two had died, while one had relocated to another province. The intention of meeting them in 2015

(c) Chux Gervase Iwu, 2017.

Chux Gervase Iwu, Professor, HoD: Entrepreneurship and Business Management, Cape Peninsula University of Technology, South Africa.

This is an Open Access article, distributed under the terms of the Creative Commons Attribution-NonCommercial 4.0 International license, which permits re-use, distribution, and reproduction, provided the materials aren't used for commercial purposes and the original work is properly cited. was to accomplish objective 2 of the study: to find out how they had fared. The researcher, then, met with them in February 2015.

This paper, therefore, has two main aims, namely, to report the initial findings (anticipated needs) and, secondly, to detail how the recipients have coped with the challenges and the current status of the business. Perhaps the findings will provide better insight into the "myth" that small businesses fail within 2-3 years and possibly uncover likely redemptive practices. There is no doubt that this study holds significant value to both practitioners and scholars.

The study took place in South Africa specifically in Western province. All the recipients were residents of Western Province at the time this study commenced.

The paper is structured as follows: the next section is literature review, which briefly conceptualizes the benefits of entrepreneurship, the environment necessary for entrepreneurship and the role of funders. Next is the research design section, which explains the methodology that was employed for the study. Thereafter, the results are presented and discussed. And finally, the report is concluded with recommendations for practitioners, scholars, government and other stakeholders.

\section{Literature review}

1.1. The benefits of entrepreneurship in a society. For many years now, entrepreneurship has been considered as one of the most important solutions to the three-pronged challenges of most African countries. These challenges include unemployment, pov- 
erty and low economic growth, thus, necessitating the creation of new ventures and providing support to existing ones. According to Ahl (2006), businesses are critical to the advancement of any economy owing to their capacity to provide jobs, thus, curbing total dependence on the government by citizens. In fact, Herrington, Kew and Kew (2010) are also in agreement by stating that entrepreneurial activity stimulates economic growth through job creation and innovation.

Unemployment rate in South Africa continues to grow. This suggests that only very few people in South Africa are economically active. A situation of this kind does not augur well for a country that continues to attract thousands of economically disadvantaged citizens of other nations. In fact, the unrelenting attractiveness of South Africa comes from other nationals' (citizens of other sub-Saharan and several emerging economies) perceptions of South Africa's capacity to provide the opportunities, which they lack in their home countries. While the question of whether South Africa has the potential to provide and sustain this longing can be located within the spheres of South Africa's economic policies, it is instructive to add nonetheless that certain economic policies have focused on providing support for small and micro businesses. The issue of implementation, however, renders the policies vulnerable.

1.2. The environment necessary for entrepreneurship. Many scholars are of the view that for entrepreneurial activity to blossom in any economy, it requires the right kind of environment. These include accessible support agencies (Gwija et al., 2014a); access to funding (Gwija et al., 2014b); support networks (Xesha et al., 2014); training and development opportunities (Iwu \& Nxopo, 2015); and improved government support (Herrington, Kew \& Kew, 2010).

Nxopo (2015), referring to the 2008 GEM report, suggests a number of recommendations (see Table 1 below) for the enhancement of entrepreneurship in South Africa.

Table 1. Recommendations to improve entrepreneurship in South Africa

\begin{tabular}{|c|c|}
\hline Category & Recommendations \\
\hline $\begin{array}{l}\text { Education and train- } \\
\text { ing }\end{array}$ & $\begin{array}{l}\text { Improve basic education, with special emphasis on numeracy, literacy and vocational training. } \\
\text { Improve education in business skills at school level to stimulate entrepreneurial capacity in the youth including the extension } \\
\text { of financial literacy and vocational training programs to the unemployed. } \\
\text { Establish a wide-ranging apprenticeship system to provide artisan skills, especially to young people. } \\
\text { Provide up-to-date training programmes that focus on the entrepreneurs' needs, rather than outdated programmes that cater } \\
\text { predominantly for general managers. } \\
\text { Entrepreneurial trainers and consultants must themselves be well-trained and/or experienced in the specific area of expertise } \\
\text { they offer. Enterprise support programs must be properly and regularly evaluated, and constantly improved. }\end{array}$ \\
\hline Government policies & $\begin{array}{l}\text { Introduce policies that reduce the cost of doing business. } \\
\text { Simplifying business registration procedures. } \\
\text { Simplifying tax regulations for start-up entrepreneurs; incentivize entrepreneurship through greater development of special- } \\
\text { ised economic zones, providing tax breaks for businesses below certain revenue thresholds and lowering barriers to entry in certain } \\
\text { industries. } \\
\text { Liberalize the labor market, or introduce a two-tier labor market with increased flexibility for smaller companies. Refine the } \\
\text { Preferential Procurement Act and institute better performance management of the implementers of the Act. }\end{array}$ \\
\hline Financial support & Simplify funding application processes to accommodate the reality of the majority of South African entrepreneurs. \\
\hline Others & $\begin{array}{l}\text { Create clusters/incubators/business hubs, including entrepreneurs and commercial and professional support structures, so } \\
\text { that start-ups can be assisted in a more protected and supportive environment. }\end{array}$ \\
\hline
\end{tabular}

Source: Nxopo, 2015, (Adapted).

It is clear from the above table that entrepreneurship thrives in an environment, which encourages and provides access to training programs such as financial literacy, wide-ranging apprenticeship system in the form of clusters/incubators andor business hubs. The table above also indicates that entrepreneurship thrives in an economic system that favors simplified business start up protocols. It is also clear that there is a significant need for funders to play active roles in not only awarding funds, but also in monitoring the recipients to identify challenges on time.

\subsection{The role of funders - government and private} institutions. Boosting entrepreneurial activity requires the support of both public and private agencies. In South Africa, for instance, there are several initiatives by government that aim to provide the necessary support for small businesses and entrepre- neurs. Although there are concerns whether these agencies are living up to their expectations (Gwija et al., 2014a), yet they are expected to, among others, “....expand, co-ordinate and monitor the provision of training, advice, counselling and any other nonfinancial services to small business in accordance with the National Small Business Support Strategy" (Ntsika, 2003). Interestingly, a new department for small business development has been created by South African government to cater for and provide a conduit for small businesses to reach out and access support. However, one of the criticisms levelled against government support agencies is that they fail to monitor those who receive financial support from them (Lerner, 1999). Continuous monitoring and evaluation provide the necessary wedge against poor performance of businesses. With continuous monitoring, it is possible to identify a recipient who is strug- 
gling with his business. In this case, the recipient may receive help timeously reducing the likelihood of collapse. Studies report a number of early stage small business issues, which hinder business growth in subSaharan Africa. These issues range from negative cash flows, which are attributable to "a lack of sales, pricing problems, high competition, low demand, and, most often, soaring operating costs" (Okpara \& Wynn, 2007), to poor educational foundations owing to educational disparities and governments' disinvestment in education (Nichter \& Goldmark, 2009).

\section{Design}

So much has been said with respect to the life span of small businesses, especially in South Africa. The commonly held notion is that they do not survive beyond 2-3 years of existence. Therefore, to understand what this means - whether it is a myth or reality and the real causes - requires an in-depth examination. Owing to this consideration, a three-pronged research program was designed. The first stage of the program focused on 27 beneficiaries of a small business funding. They were asked to identify what they envisaged as their major and minor challenges. In other words, what did they foresee as the challenges they would confront in their businesses?

The second phase involved distilling the responses to the questionnaire to enable the development of openended, semi-structured interview questions. The intention was to elicit information and gain better insight into the challenges of small businesses pre and post startup. During the third stage, which took place almost 3 years after the first stage, the researcher held interviews with each of the recipients (this time, 24 participants) at their business locations. The researcher considered the three-pronged, mixed method ideal for this study because of its capacity to reveal information that will assist both practitioners and scholars alike to be better equipped to deal with the myth that most small businesses do not survive longer than their first two to three years of existence. This was also what informed the researcher to undertake a longitudinal study.

Longitudinal studies are the most appropriate for investigating changing attitudes or perceptions over a certain time period (Terre Blanche et al., 2012). Essentially, they permit the initial listing of different perceptions in order to make comparisons at a later stage. For instance, in the case of this research, participants were asked to identify, from a list of items, those they perceived as major challenges and minor challenges. To correctly assess the value of agency funding requires a longitudinal review of the progress of fund recipients. This is the line towed by this study. Longitudinal studies are necessary, especially in entrepreneurship, because it is commonly stated that most small businesses fail within the first 2-3 years of start up.

2.1. Instruments. The questionnaire administered to the participants had eight items (see table below) and they were requested to indicate (by inserting an ' $x$ ') on a two-point Likert scale which of the items anticipated would pose a major or minor challenge to them. The items in the questionnaire were adapted from various studies (for example, Choto et al 2014; Eresia-Eke \& Rath, 2013), which found related issues as major challenges of small businesses in South Africa. The researcher also acknowledges Richard Monk's (2000) article that listed the important business skills that small businesses must have to succeed. Monk's article and the others provided the necessary validation opportunity for the items in the questionnaire (see Table 2 below).

Table 2. Questionnaire items

\begin{tabular}{|l|l|l|}
\hline \multicolumn{1}{|c|}{ Items } & Major challenge & Minor challenge \\
\hline How to record sales & & \\
\hline How to record purchases & & \\
\hline How to balance books & & \\
\hline How to do banking & & \\
\hline The discipline to separate business finance from personal finance & & \\
\hline How to order stock & & \\
\hline How to inform people in the community about your business & & \\
\hline How to manage employees & & \\
\hline
\end{tabular}

From the table above, it is clear that the first 5 items can be located within the realm of financial management. The rest are within marketing and human resource management disciplines.

Interviews were conducted with 24 participants. The interviews were recorded with the help of a voice recorder. Labels were used to identify each of the participants to avoid wrong listing. Each of the participants was interviewed alone in the presence of an interpreter.
With the exception of the demographic questions, the interview questions were essentially reflective of the items in the questionnaire which was distributed to the participants in 2012. Principally, the qualitative instrument developed by Kohli and Jaworski (1993) was instrumental in framing the interview questions.

2.2. Ethics. The study was merely an academic exercise executed on the basis of the researcher's interest in entrepreneurship and business develop- 
ment. These were the major credentials presented to the funders who consented to the study. An adjunct to the right to conduct the study was that the findings would be disclosed to the funders upon completion. It was also agreed that the identities of everyone involved in the study would not be disclosed. This particular agreement influenced the structure of the questionnaire (see Appendix). For instance, the participants were not required to state their names, as well as the location of their businesses. Ethical research conduct requires any researcher to ensure that none of the participants or the funding agency was harmed in any way during the study. Unauthorized disclosure of identity and or location of businesses will constitute a disregard of the agreement.

\section{Findings and discussion}

3.1. Participants' business types and demographic profiles. The key informants comprised 27 subjects. Unfortunately, by 2015 , the number had reduced to 24. The types of businesses the participants were involved in are listed below in Table 3.

Table 3. Fund recipients' businesses

\begin{tabular}{|c|c|c|}
\hline Type of business & Male & Female \\
\hline Car repair service & 2 & 0 \\
\hline Dress making/Fashion design & 4 & 3 \\
\hline Internet café & 3 & 1 \\
\hline Kasi' restaurant & 2 & 3 \\
\hline Township tour agency & 1 & 2 \\
\hline Spaza² shop & 4 & 2 \\
\hline Total & 16 & 11 \\
\hline
\end{tabular}

Notes: ${ }^{1}$ The term Kasi generally means township, and is popularly used in such townships, especially by young people to distinguish between "informal" and up-market restaurants such as MacDonald, and KFC. ${ }^{2}$ Spaza shop is an isiZulu concept, which was used to define informal businesses that were secretly operated from home by Black South Africans selling petty goods/groceries to make a living (Bear et al., 2005).

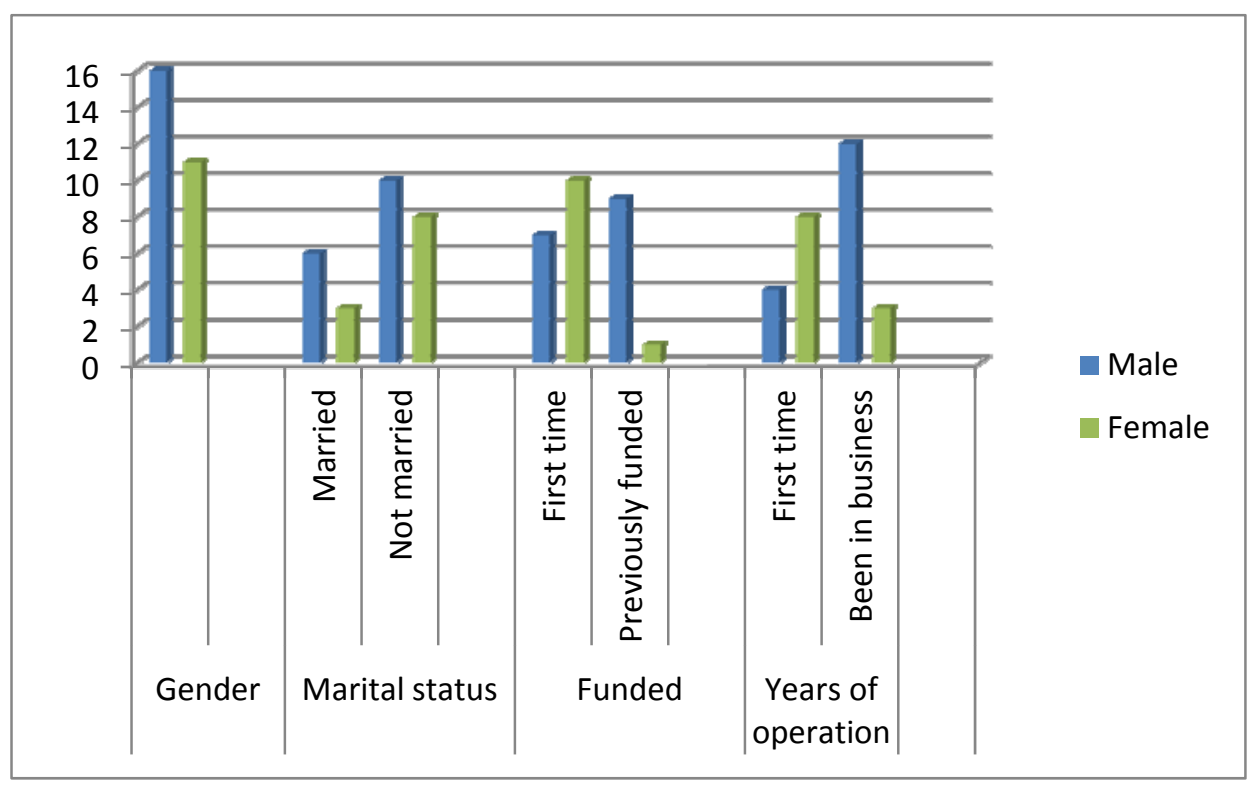

Fig. 1. Breakdown of participants' profile

The table above shows that sixteen males and eleven females participated in the study (please note that these were the original participants in exclusion of the three that did not participate in the follow up study). Six of the sixteen males were married, while eight females were not married. With respect to how long the participants had been in business, twelve males and one female, respectively, had been in business before the fund, while four males and eight females were in business for the first time. Nine men had been recipients of funds, while only one female received funds in the past.

3.2. Analysis of $1^{\text {st }}$ meeting's (2012) findings. The first meeting with the recipients of the fund took place at the funder's office.

The initial indications pointed in the direction of serious financial management challenge except for item 7, which falls within the discipline of marketing. See figure below. 


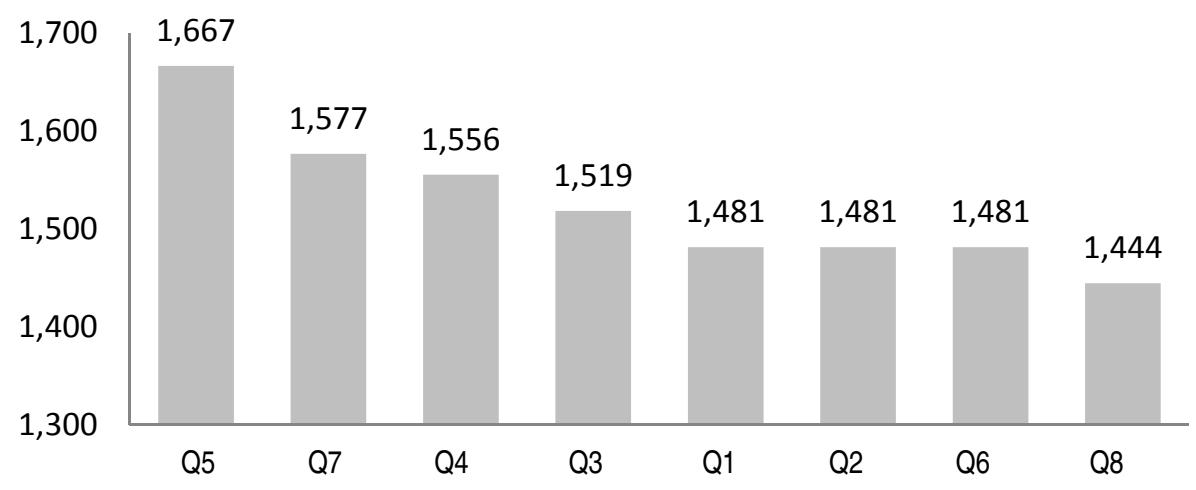

Fig. 2. Mean (major challenges)

The above table presents the eight items in the questionnaire. "How to manage employees" was identified as a minor challenge by the participants. With the exception of the marketing-related item (Q7: $1.577)$, it is obvious from the table above that the majority of the participants anticipated financial management issues to be more challenging.
With respect to which items in the questionnaire were major challenges and which were minor challenges, the table below (Table 4) indicates that only "how to manage employees" scored a lot less than all the other items in the category of major challenges.

Table 4. Responses per item (major challenges versus minor challenges)

\begin{tabular}{|l|l|c|c|}
\hline \multicolumn{2}{|c|}{ Responses per item (major and minor challenges) } \\
\hline & \multicolumn{1}{|c|}{ Items } & Major challenge & Minor challenge \\
\hline Q1 & How to record sales & $48 \%$ & $52 \%$ \\
\hline Q2 & How to record purchases & $48 \%$ & $52 \%$ \\
\hline Q3 & How to balance books & $52 \%$ & $48 \%$ \\
\hline Q4 & How to do banking & $56 \%$ & $44 \%$ \\
\hline Q5 & The discipline to separate business finance from personal finance & $67 \%$ & $33 \%$ \\
\hline Q6 & How to order stock & $48 \%$ & $52 \%$ \\
\hline Q7 & How to inform people in your community about your business & $58 \%$ & $42 \%$ \\
\hline Q8 & How to manage employees & $44 \%$ & $56 \%$ \\
\hline
\end{tabular}

From the above table, $67 \%$ of the participants identified "The discipline to separate business finance from personal finance" as a major challenge. Adisa, Abdulrahim and Mordi (2014) also found among others that owner/manager inability to distinguish business capital and personal saving was a major challenge in Nigeria. Participants who indicated that "informing people in their community about their businesses" was a challenge amounted to $58 \%$.
3.3. Gender distribution with regard to anticipated challenges. In general, male participants who identified the challenges as major were below $50 \%$ on most of the items. $38 \%$ of them were married, $44 \%$ were previously funded, while only $25 \%$ were already in business. The figure below depicts further.

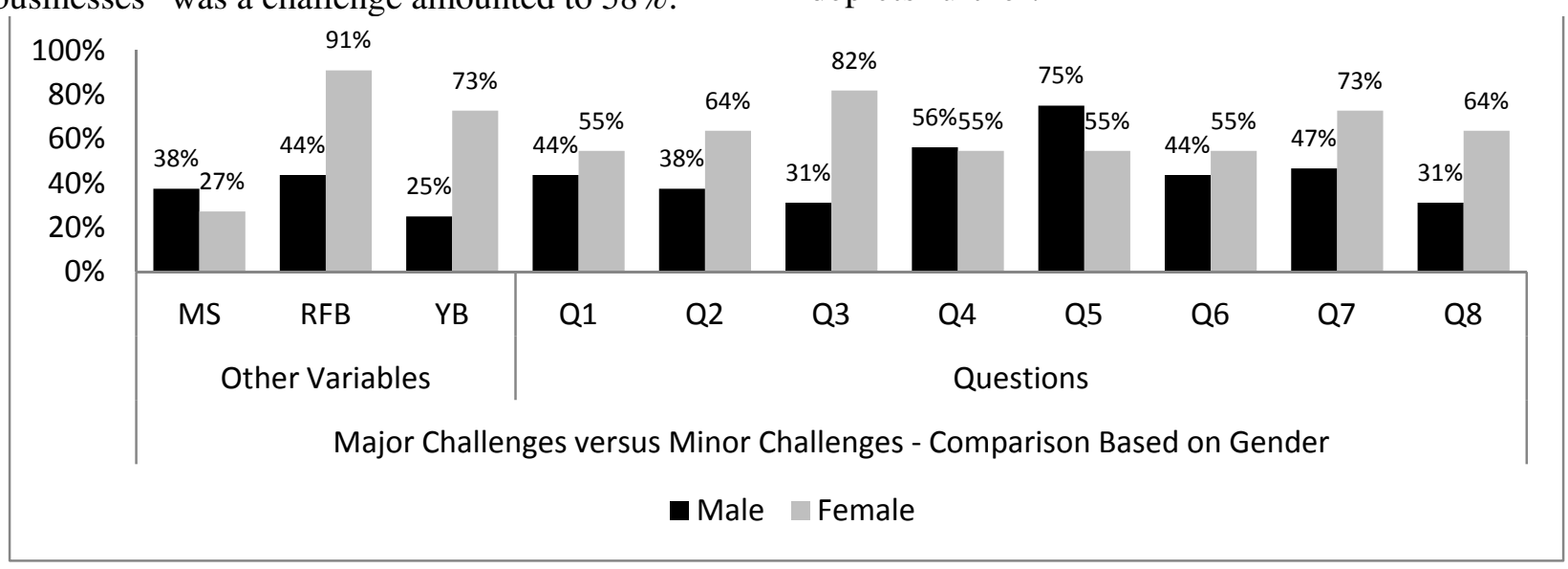

Fig. 3. Major challenges versus minor challenges - comparison based on gender 
The above table also shows that $91 \%$ of the female participants received funds for the first time compared to $44 \%$ of the male participants. This is in line with the $73 \%$ of women who indicated that they were in business for the first time compared to male, $25 \%$ are married, and $75 \%$ indicating they have been in business. This suggests that most males had previously received some form of funding than the female participants.
3.4. Marital status distribution with regard to anticipated challenges. Of those who are married, $67 \%$ are male, $33 \%$ received funds before and $33 \%$ are in business for the first time. Generally, less than $50 \%$ of the participants identified more than half of items as major challenges. Figure 4 below depicts further.

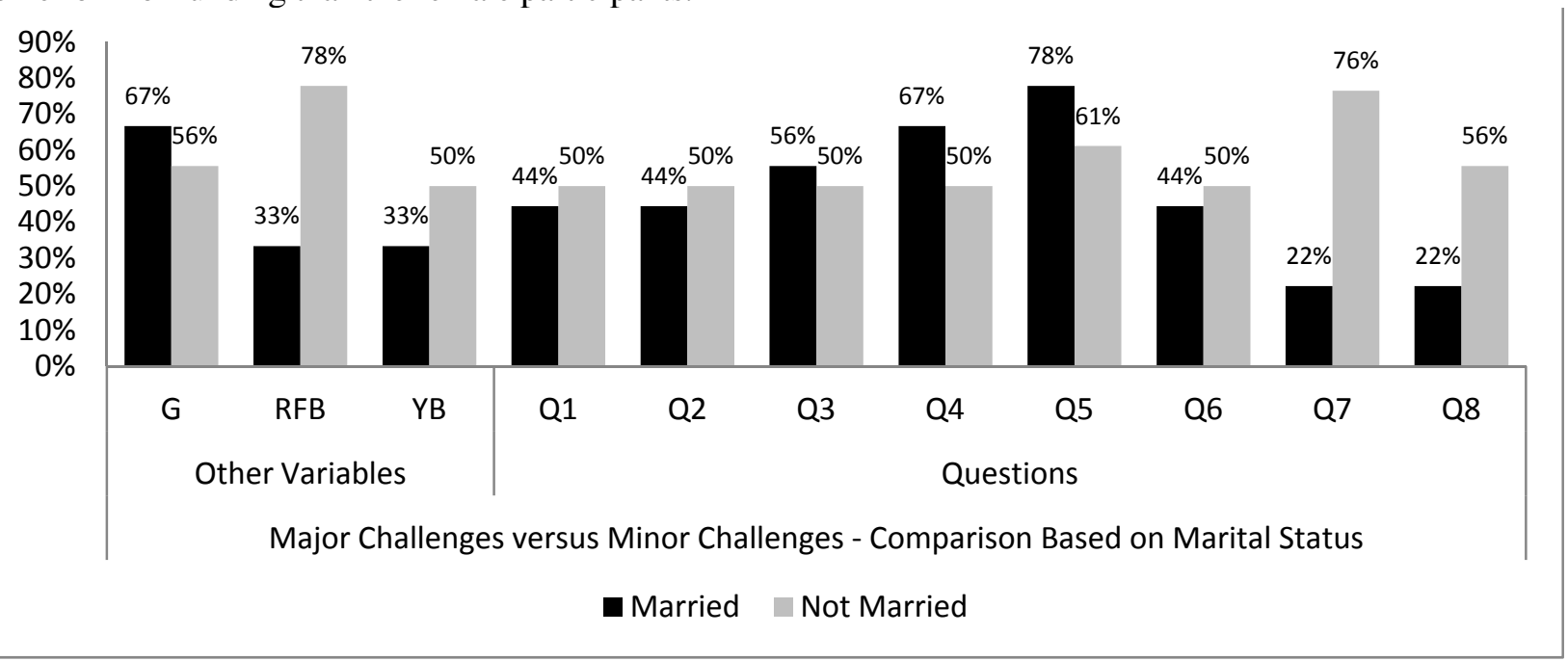

Fig. 4. Major challenges versus minor challenges - comparison based on marital status

Key: $\mathrm{G}=\mathrm{Gender}$; RBB=Received funds before; $\mathrm{YB}=$ Years in business

Regarding unmarried participants, the findings are as follows: $56 \%$ were male, $78 \%$ received funds for the first time, and half of them were already in business. Generally, in all the questions asked, unmarried participants identified all the questions as major challenges as indicated by a $50 \%$ and above on all questions.
3.5. Prior fund recipient vs. anticipated challenges. Of those who received funds for the first time, only $18 \%$ were married, $41 \%$ were males while $71 \%$ of the participants were in business for the first time. Out of those who previously received funds, $60 \%$ were married, $90 \%$ were male and all of them were in business for the first time.

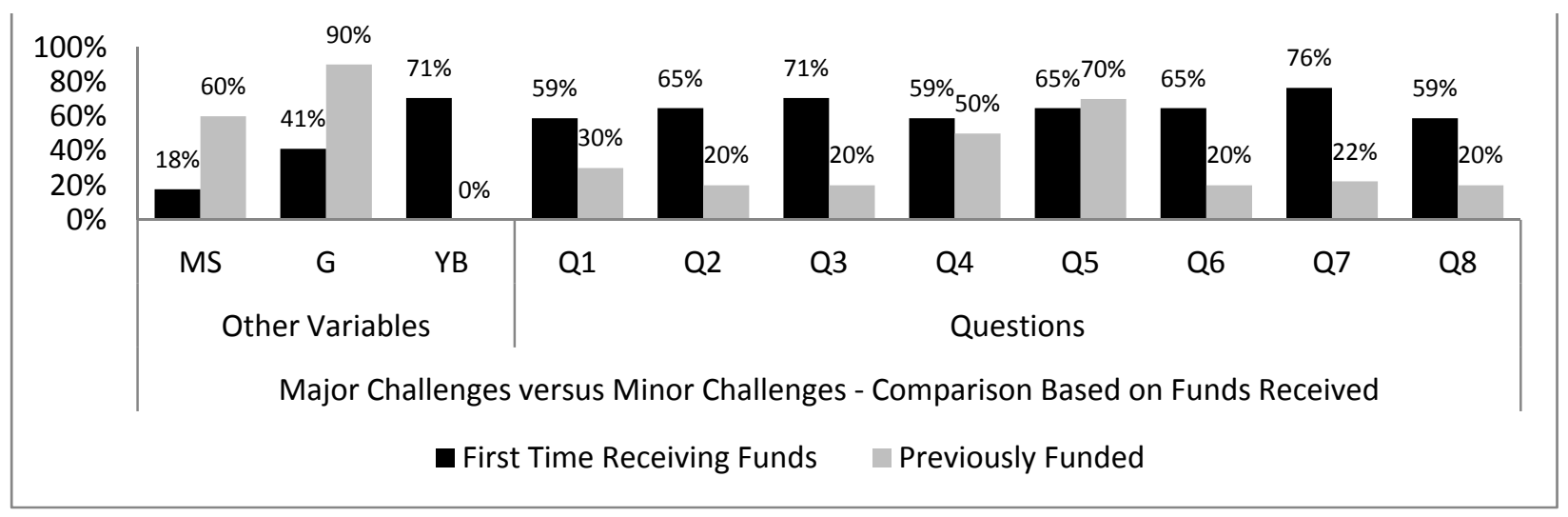

Fig. 5. Major challenges versus minor challenges - comparison based on funds received

Notes: MS=Marital status; $\mathrm{G}=\mathrm{Gender} ; \mathrm{YB}=$ Years in business.

Those who received funds for the first time perceived the items as major challenges. Evidence is in at least $59 \%$ of them who identified each item as a major challenge. This would suggest that they are still new in the business, as $71 \%$ of them indicated that it was their first time in business. On the other hand, less than $21 \%$ of those who were previously funded indicated that most of the questions asked were not major challenges.
3.6. Major challenges - comparison based on business experience (first time in business versus previously in business). Of those who indicated that they had been in business, $25 \%$ were married; all of them received the current funding and only $33 \%$ were male. Most participants indicated that almost all the items in the questionnaire were major challenges, as more than $66 \%$ agreed to this in seven 
out of the eight questions. This could be, because this is their first time being in business, hence, participants are yet to be exposed to these challenges. On the other hand, $40 \%$ of those who had been in business were married, $33 \%$ received funding and $80 \%$ are male. Only a small number $(50 \%$ and below) identified the questions asked as major challenges. This could suggest that they were familiar with the challenges and knew how to manage them.

3.7. Second meeting's (2015) findings. Questions asked during the interviews reflected the items in the questionnaire, which was distributed to participants in 2012 .

Firstly, each of the participants was asked: From the time you received the money until now, how do you assess the performance of your business? Those who indicated that they had issues were asked follow up questions. For instance, a female participant said she was the sole breadwinner whom every family member relied upon. She also added, "in the beginning I kept the shop open until late before I was robbed. And many shop items were stolen". Following this response, the researcher casually asked why she didn't insure the place. Her response was "is it not expensive?" In the researcher's view, that was an indication that she was not informed about the need for this or she was unaware of how to go about insuring her business. The researcher also thought the funders should have arranged some form of insurance for the recipients considering the high rate of burglary in many of the recipients' business locations as well as to safeguard the funds somewhat.

A more direct answer came from three of the participants. One said "I think the business is doing well. For now, I have been able to maintain regular purchases of my stock. I have also been able to maintain the salary of myself and the people who help out". A male participant said "I am confident that this business will survive because I am happy with the way my business is doing". Another respondent said in a matter of fact tone: "to be honest with you, I am struggling." Because this was unclear to the researcher, clarity was sought for which the researcher was told "this is my first time in business...I am scared of losing it". This sounded to me like an honest disclosure of the pressures that accompany female business owners, i.e., the need to do well. In fact, Maas and Herrington (2007) aptly said "If women entrepreneurs fail, the environment is less sympathetic towards them".

When asked how the business had fared since receiving the fund, another interesting response from another female participant confirmed a common challenge of female entrepreneurs, i.e., the role of females in families. A participant said "I am a single mother of four. My first born is about to complete university and there are others who are also in school".
Some of the participants said the following:

I trust some people so I sell to them when they say they will pay later. But they don't bring my money.

\section{I find many items missing in the shop. I don't know how.}

A case of losing customers was alluded to when one of the respondents declared: It's not easy to leave the shop to any of the people here. If I go to buy stock, I am always anxious about how my shop will be managed. In the event that this respondent went out to procure items for the business, the researcher assumed that the business owner locked up the store for as long as he was away.

A significant response came from one of the participants: I think I was happy in the first year of the business. But after that I have been struggling. When asked why he felt that way, the participant said two new shops were set up next to his and they sold at much cheaper prices compared to his. The respondent went further to say that the two shops were owned by a Somalian and someone from Africa (a common way of identifying a non South African, non-Somalian, but of African origin). Another participant also said: Since I came here, the rent has been going up. I think if I can get a place where the rent is fine, I can do better. This is perhaps in reference to the presence of immigrant retail entrepreneurs who are willing to pay high rental fees.

A female participant said "when people come into the shop, the way they ask for something as if I am a staff here". This points in the direction of the female business owner feeling unrecognized as a business owner, but rather looked down upon as a mere employee. This somewhat relates to Bruni et al. (2004) statement that females tend not to be recognized as achievers.

Interestingly none of the participants revealed any issues with managing their finances beside the participant who said he had issues with getting paid by his debtors. All the participants said they kept record of their daily sales and expenditures in a ledger. Surprisingly the ledgers were donated by the funding agency. The funding agency requires them to hand in the ledgers to an appointed tax consultant who did their books over the years.

Of interest again is that none of the previously funded (business owners) indicated any issue with managing their businesses. It is surprising that only very few of the respondents considered management of personnel as a major challenge to the running of their businesses. The researcher's assessment of this finding is that the respondents do not consider their "employees" as employees either because they are hired informally or those who assist in the business are family members. Effective business management requires that business owners should view 
anyone who works in the business as an employee so that proper documentation is kept of their performance and they are remunerated. As reported earlier, one of the participants said it's not easy to leave the shop to any of the people here. If I go to buy stock, I am always anxious about how my shop will be managed. This is a classical trust issue. If someone works in the business, he should be assigned some responsibility that he has to account for. Therefore, this particular participant should be able to run other errands in the business, while an employee looks after the business. Growth in any business demands the performance of every employee. Employees add value to any business especially if they execute the tasks that they are assigned (Kappo-Abidemi et al., 2015). It is, therefore, necessary that they are remunerated accordingly. If an employee is not adequately remunerated, the likelihood is that he may engage in behaviors that are incongruent to the values of the business.

\section{Conclusion}

It has been reported that small businesses do not survive beyond 2-3 years of existence, because they confront a host of challenges. Many of the reasons for this have been disclosed here in this report. But not all of them have been unravelled, as this study has shown. For instance, the issue of trust alluded to by one of the participants who was uncomfortable with leaving his place of business in the care of anyone while on a business errand.

A case for effective mentoring and business networking is made here following the respondent who said "this is my first time in business...I am scared of losing it". It is important to stress that mentoring has the capacity to diffuse fears, while stories that are shared in networks help to uplift the morale of network members. With respect to mentoring, Bozionelos et al. (2014) affirm that openness to experience, as well as agreeableness can serve the protégé in good stead. What this means is that the mentee must be willing to learn and be exposed to the best possible business experience.

Another issue that has emerged from this study is that of pilfering in stores. This is a serious matter that can render any new small business and, in fact, any business for that matter unprofitable. Again, this is perhaps an issue of trust. If a small business owner is unable to trust an employee to execute some of the responsibilities in the business, the likelihood is that the employee will not be reasonably effective in attending to customers, or even notice when customers pilfer items from the store. It also emerged from this study that majority of the participants $(56 \%)$ considered employee management as a minor challenge. The most reasonable deduction to make from this is that the participants do not think it is necessary to hire anyone for the business if they could informally recruit someone.
This someone could be a family member. Also not hiring someone may be linked to affordability. Affordability calls to question the cost of hiring an employee. Perhaps at this stage, one should examine the amount of money available to a new business. While agency funding ought to match the startup cost of any new business, one wonders whether the cost of hiring an assistant is factored into the business plan. But even then, a small business may be hampered by very complex labor market policies of government.

This study's main aims were to find out from the recipients what they envisaged as their main challenges, and to compare those challenges at a later stage to get a better understanding of the real challenges of small business pre and post startup. The ultimate benefit will be to report on these to inform practitioners and researchers so that every stakeholder can have a fresher insight into this phenomenon with the hope that much more concrete discussions and interventions may emerge. To this end, the following are proposed:

- Merely providing funds without commensurate appurtenances will result in recipients not particularly crediting the business with the requisite attention. The provision of a monitoring team to oversee the recipients over a period of time say the first three years is a worthwhile investment. It is fair at this juncture to commend this financier for making available a team of financial/accounting practitioners to assist the recipients with simple book keeping practices and other allied financial management activities. This study acknowledges that if the recipients did not receive this support they may have struggled with keeping their records and, as a result, declare financial management as one of their challenges thereby affirming the commonly held notion that inability to manage finance results in small business failure.

- Creation of access and channels for extra support that businesses are not able to source ordinarily. A good example will be accessible nonprofit business organizational formations that provide workable understanding of time management, personnel relations, marketing and collaborative partnerships such as the model used by Somalis in South Africa.

- The use of role models is also suggested. This role can be played by both government institutions and private establishments. Research has shown that people tend to look up to society's exceptional individuals who are bold to share their stories and use those to teach both practising and aspiring entrepreneurs to do things better.

- Entrepreneurship education from early age can serve as a significant stimulant for the youth to become entrepreneurs. 
This study focused on small businesses which are considered vital for sustained socioeconomic growth. This benefit of small businesses to an economy is even more desired in South Africa, a nascent democracy with the paraphernalia of modernity, but with an increasing high number of youth unemployment. Again, South Africa is not among the sub-Saharan African countries who can boast of a relatively impressive total early-stage entrepreneurial activity (TEA). In light of this, it is crucial for government and private establishments to work together in reversing this trend, and also pay more attention to small business issues so that they can contribute significantly to socioeconomic development of the nation.
This study should generate the necessary momentum for discussions that focus on determining small business growth constraints in sub-Saharan Africa, specifically South Africa. It is hoped that both practitioners and scholars are enthused enough to engage in research that uncovers some of the undocumented challenges of small businesses so that their chances of surviving beyond the 2-3 year mark are improved.

\section{Acknowledgments}

The researcher thanks Mr. Lucky Sibanda of Supreme Educators Inc. South Africa for assisting with data collation.

\section{References}

1. Adisa, T. A., Abdulraheem, I., and Mordi, C. (2014). The Characteristics and Challenges of Small Businesses in Africa: an Exploratory Study of Nigerian Small Business Owners. Economic Insights-Trends and Challenges, 3(4), 1-14.

2. Ahl, H. (2006). Why research on women entrepreneurs needs new directions, Entrepreneurship Theory and Practice, 30(5), 595-621.

3. Bear, M., Bradnum, P., Tladi, S., \& Pedro, D. (2005). Making retail markets work for the poor - why and how Triple Trust Organisation decided to intervene in the spaza market in South Africa. Washington, D.C.: The SEEP Network.

4. Blanche, M. T., Durrheim, K., \& Painter, D. (2012). Research in practice: applied methods for the social sciences. Juta and Company Ltd.

5. Bozionelos, N., Bozionelos, G., Polychroniou, P., \& Kostopoulos, K. (2014). Mentoring receipt and personality: Evidence for non-linear relationships. Journal of Business Research, 67(2), 171-181.

6. Bruni, A. G., Gherardi, S., \& Poggio, B. (2004). Entrepreneurs-mentality, gender and the study of women entrepreneurs. Journal of Organisational Change Management, 17(3), 256-268.

7. Choto, P., Tengeh, R. K., \& Iwu, C. G. (2014). Daring to survive or to grow? The growth aspirations and challenges of survivalist entrepreneurs in South Africa. Environmental Economics, 5(4), 93-101.

8. Eresia-Eke, C.E. \& Raath, C. (2013). SMME Owners' Financial Literacy and Business Growth. Mediterranean Journal of Social Sciences, 4(13) 397-406.

9. Gwija, S. A., Eresia-Eke, C., \& Iwu, C. G. (2014a). Assessing the impact of support structures and initiatives to youth entrepreneurship development in a selected Township in the Western Cape Province of South Africa. Mediterranean Journal of Social Sciences, 5(1), 61-68.

10. Gwija, S. A., Eresia-Eke, C., \& Iwu, C. G. (2014b). Challenges and Prospects of Youth Entrepreneurship Development in a Designated Community in the Western Cape, South Africa. Journal of Economics \& Behavioral Studies, 6(1), 10-20.

11. Herrington, M., Kew, J., \& Kew, P. (2010). Global Entrepreneurship Monitor (GEM), South African Report 2009. Cape Town: University of Cape Town, Graduate School of Business.

12. Iwu, C. G., \& Nxopo, Z. (2015). Determining the specific support services required by female entrepreneurs in the South African tourism industry. African Journal of Hospitality, Tourism and Leisure, 4(2), 1-13.

13. Kohli, A. K., \& Jaworski, B. J. (1993). MARKOR. A measure of market orientation. Journal of Marketing Research, 30 (November), 467-477.

14. Kappo-Abidemi, C., Iwu, C. G., \& Allen-Ile, C. (2015). Retaining and properly developing employees: could this impact professional conduct? Corporate board: role, duties and composition, 11(3), 84-92.

15. Lerner, J. (1999). The government as venture capitalist: the long-run impact of the SBIR program. Journal of Business, 72(3), 285-318.

16. Maas, G., \& Herrington, M. (2007). Global Entrepreneurship Monitor (GEM), South Africa Report 2006. Cape Town: University of Cape Town, Graduate School of Business.

17. Monk, R. (2000). Why small businesses fail? CMA Management, 74(6), 12-13.

18. Nichter, S., \& Goldmark, L. (2009). Small firm growth in developing countries, World development, 37(9), $1453-1464$.

19. Ntsika Enterprise Promotion Agency. (2003). State of small business in South Africa. Pretoria, Ntsika, Policy and Research Division.

20. Nxopo, Z. (2015). The role of government in empowering female entrepreneurs in the Western Cape, South Africa. MTech thesis, Cape Peninsula University of Technology, South Africa.

21. Okpara, J. O., \& Wynn, P. (2007). Determinants of small business growth constraints in a sub-Saharan African economy. SAM Advanced Management Journal, 72(2), 24-35.

22. Xesha and Kesha, D., Iwu, C. G., \& Slabbert, A. (2014). Business relationships as a driver of success for small, medium, and micro enterprises (SMMEs) in South Africa. Journal of Economics, 5(1), 37-43. 
Appendix

Anticipated challenges on award of funds - Questionnaire

Instruction: Whichever applies to you, please indicate with an $\boldsymbol{X}$. Thank you. Please see example below:

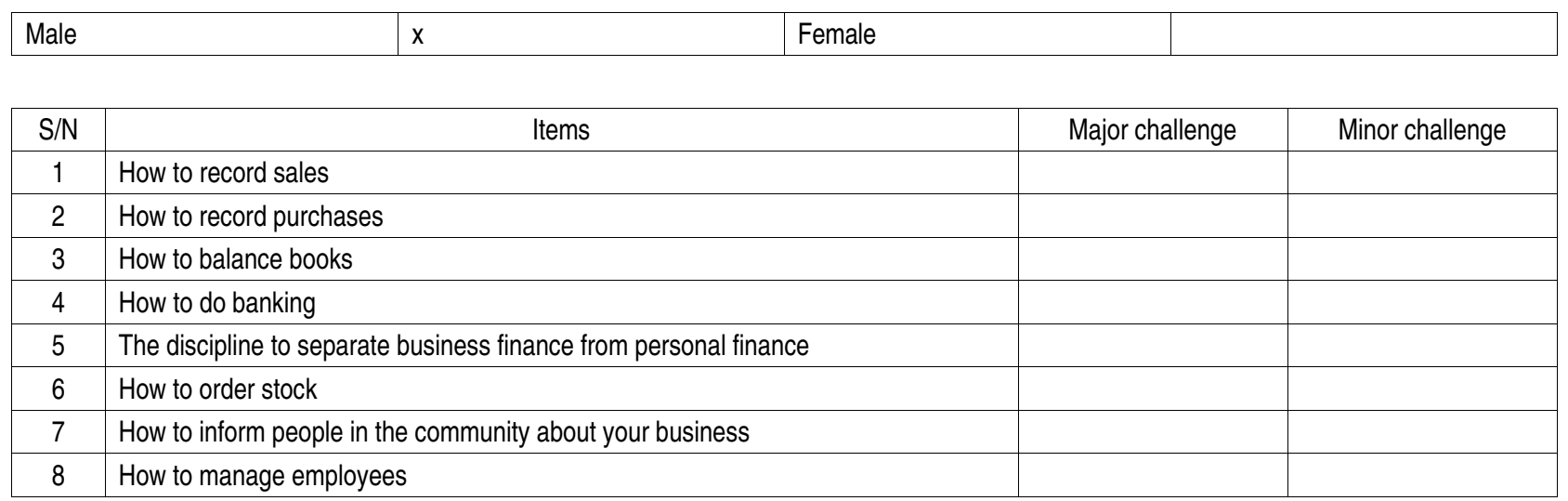

Gender

\begin{tabular}{|l|l|l|l|}
\hline Male & Female & \\
\hline
\end{tabular}

Marital status

\begin{tabular}{|l|l|l|l|}
\hline Married & Not married & \\
\hline
\end{tabular}

Received funds before

\begin{tabular}{|l|l|l|}
\hline First time receiving funds & Previously funded \\
\hline
\end{tabular}

Years in business

\begin{tabular}{|l|l|l|}
\hline First time in business & & Been in business \\
\hline
\end{tabular}

